\title{
Uji konsentrasi hambat minimum (KHM) ekstrak daun pacar air (Impatiens balsamina L.) terhadap pertumbuhan Streptococcus mutans
}

\author{
${ }^{1}$ Raymond A. Lolongan \\ ${ }^{2}$ Olivia Waworuntu \\ ${ }^{3}$ Christy N. Mintjelungan
}

\author{
${ }^{1}$ Kandidat Skripsi Program Studi Pendidikan Dokter Gigi Fakultas Kedokteran \\ ${ }^{2}$ Bagian Mikrobiologi Fakultas Kedokteran \\ ${ }^{3}$ Program Studi Pendidikan Dokter Gigi Fakultas Kedokteran \\ Universitas Sam Ratulagi Manado \\ Email: ray.anugrah17@gmail.com
}

\begin{abstract}
Impatiens balsamina L. is an herbal plant which contains flavonoids that has been proven to inhibit the growth of Streptococcus mutans. This study was aimed to determine the minimum inhibitory concentration (MIC) of the balsamina leaf extract on the growth of Streptococcus mutans. This was a true experimental study with a randomized pretest-postest control group design. The method used was serial dilution and tested with the spectrophotometer and turbiditry measurements. Balsamina leaf was extracted by using maceration method with $96 \%$ ethanol. The Streptococcus mutans bacteria were obtained from pure stock bacteria at Microbiology Laboratory of Pharmacy Faculty of Mathematics, University of Sam Ratulangi. The results indicated that the minimum inhibitory concentration (MIC) of the balsamina leaf (Impatiens balsamina L.) extract on the growth of Streptococcus mutans was at a concentration of $3.125 \%$.
\end{abstract}

Keywords: balsamina leaf (Impatiens balsamina L.), Streptococcus mutans, MIC

\begin{abstract}
Abstrak: Pacar Air (Impatiens balsamina L.) merupakan tanaman herbal yang mengandung flavonoid yang telah terbukti dapat menghambat pertumbuhan Streptococcus mutans. Penelitian ini bertujuan untuk mengetahui konsentrasi hambat minimum (KHM) dari ekstrak daun Pacar Air terhadap pertumbuhan Streptococcus mutans. Jenis penelitian ialah eksperimental murni dengan Randomized Pretest-Posttest Control Group Design. Metode yang digunakan dalam penelitian ini yaitu metode serial dilusi dengan metode pengujian turbidimetri dan spektrofotometri. Daun Pacar air diekstraksi dengan metode maserasi menggunakan pelarut etanol 96\%. Bakteri Streptococcus mutans diperoleh dari stok bakteri murni Laboratorium Mikrobiologi Program Studi Farmasi Fakultas MIPA Universitas Sam Ratulangi. Hasil penelitian ini menunjukkan bahwa konsentrasi hambat minimum (KHM) ekstrak daun Pacar Air terhadap pertumbuhan Streptococcus mutans pada konsentrasi $3,125 \%$.
\end{abstract}

Kata kunci: daun pacar air (Impatiens balsamina L), Streptococcus mutans, KHM

Kesehatan merupakan salah satu aspek penting dalam menjalani kehidupan seharihari. Oleh sebab itu masyarakat pada umumnya selalu berusaha untuk tetap sehat, namun sebagian besar orang masih mengabaikan kondisi kesehatan gigi dan mulut mereka. Perawatan gigi sering dianggap tidak terlalu penting dan biayanya mahal, padahal kesehatan gigi merupakan bagian integral dari kesehatan secara keseluruhan.

Hingga saat ini kesehatan gigi dan mulut masih menjadi masalah. Berdasarkan Riset Kesehatan Dasar (Riskesdas) 
Nasional tahun 2013, prevalensi nasional masalah kesehatan gigi dan mulut mencapai $25,9 \%$ dan sebanyak 14 provinsi di Indonesia memiliki prevalensi masalah gigi dan mulut di atas prevalensi nasional. Salah satu penyakit dalam rongga mulut yang merupakan masalah nasional yakni penyakit karies gigi. Index DMF-T mencapai 4,6\% yang artinya kerusakan gigi penduduk Indonesia mencapai 460 buah gigi per 100 orang. ${ }^{1}$

Karies merupakan suatu penyakit jaringan keras gigi yaitu email, dentin dan sementum yang disebabkan oleh aktivitas suatu jasad renik dalam suatu karbohidrat yang dapat diragikan. Empat faktor etiologi utama karies yaitu host, substrat, bakteri dan waktu. Streptococcus mutans merupakan salah satu bakteri penyebab karies. ${ }^{2}$

Streptococcus mutans merupakan kuman kariogenik karena mampu segera membuat asam dari karbohidrat yang dapat diragikan. Bakteri ini dapat tumbuh subur dengan suasana asam dan dapat menempel pada permukaan gigi karena kemampuannya membuat polisakarida ekstrasel yang sangat lengket dari makanan; oleh sebab itu Streptococcus mutans sangat berperan aktif dalam terjadinya karies. ${ }^{3}$

Telah banyak upaya yang dilakukan untuk mengurangi angka karies gigi di Indonesia namun usaha tersebut belum cukup mampu untuk mengurangi angka kejadian karies gigi yang masih sangat tinggi. Berbagai upaya dilakukan untuk mengendalikan bakteri penyebab karies, salah satu upaya dengan menggunakan bahan herbal. ${ }^{4}$

Hasil penelitian terdahulu oleh Sekeon $(2015)^{5}$ melaporkan bahwa Impatiens balsamina L. memiliki kandungan flavonoid yang berfungsi sebagai antibakteri terhadap Streptococcus mutans tetapi belum diteliti konsentrasi hambat minimumnya (KHM) terhadap bakteri tersebut. KHM ialah konsentrasi antibiotik terendah yang masih dapat menghambat pertumbuhan organisme tertentu. ${ }^{5}$

\section{BAHAN DAN METODE PENELITIAN}

Jenis penelitian ini ialah eksperimental laboratorium menggunakan desain eksperimental murni dengan Randomized Pretest-Posttest Control Group Design. Penelitian ini dilaksanakan di Laboratorium Fitokimia dan Laboratorium Mikrobiologi Program Studi Farmasi Fakultas MIPA Universitas Sam Ratulangi pada bulan JuniAgustus 2016. Subjek penelitian ialah bakteri biakan murni Streptococcus mutans dari rongga mulut yang diperoleh di Laboratorium Mikrobiologi Program Studi Farmasi Fakultas MIPA Universitas Sam Ratulangi Manado.

Pembuatan ekstrak daun pacar air dilakukan di Laboratorium Farmasi M-IPA Universitas Sam Ratulangi Manado. Sampel diambil dari daerah Kawangkoan Kabupaten Minahasa. Metode yang digunakan ialah metode serial dilusi (pengenceran bertingkat) dengan perbandingan 1:2 (w/v). Metode pengujian menggunakan turbidmetri dan spektrofotometer UV-Vis.

Pembuatan media peremajaan bakteri menggunakan nutrient agar (NA) sebanyak 23 gram dilarutkan dengan 1 liter akuades menggunakan tabung Erlenmeyer, kemudian dihomogenkan dan dituang ke dalam tabung reaksi steril yang ditutup dengan alumunium foil. Media tersebut disterilkan di dalam autoklaf pada suhu $121{ }^{\circ} \mathrm{C}$ selama 15 menit. Media yang steril dibiarkan pada suhu ruangan selama 30 menit sampai media memadat pada kemiringan $30^{\circ}$.

Media Brain Heart Infusion Broth (BHI-B) ditimbang sebanyak 37 gram dan dilarutkan dalam 1 liter akuades dalam tabung Erlenmeyer, kemudian dihomogenkan. Setelah homogen media disterilisasi dalam autoklaf pada suhu $121^{\circ} \mathrm{C}$ selama 15 menit.

Pembuatan standar larutan baku McFarland 1 terdiri atas dua komponen yaitu larutan $\mathrm{BaCl} 21,175 \%$ dan $\mathrm{H} 2 \mathrm{SO} 4$ $1 \%$. Lautan $\mathrm{BaCl} 21,175 \%$ sebanyak 0,1 ml dicampur dengan larutan $\mathrm{H} 2 \mathrm{SO} 4 \quad 1 \%$ sebanyak 9,9 $\mathrm{ml}$ dan dikocok hingga homogen. Nilai absorban larutan baku McFarland 1 setara jumlah sel bakteri dengan kepadatan $0,3 \times 10^{9}$ bakteri $/ \mathrm{ml}$.

Peremajaan bakteri Streptococcus mutans yang disimpan di media agar 
diambil dengan menggunakan jarum ose steril, lalu ditanamkan pada media agar miring dengan cara menghapus, kemudian diinkubasi selama 1x24 jam.

Bakteri diremajakan pada media agar miring kemudian diambil koloninya dengan menggunakan jarum ose steril, dimasukkan kedalam media BHI-B dalam tabung reaksi, kemudian diinkubasi 1 x 24 jam. Setelah itu dilakukan pembuatan suspensi Streptococcus mutans sesuai dengan standar kekeruhan McFarland 1. Jika media BHI-B kelihatan lebih keruh dari larutan McFarland 1 tambahkan larutan salin sedikit demi sedikit kedalam media BHI-B sehingga kekeruhanya sesuai dengan kekeruhan standar McFarland 1 .

Sebanyak 11 tabung reaksi steril disiapkan. Setiap tabung uji diberi label 19, kemudian tabung 10 diberi label $\mathrm{K}(+)$ yang merupakan kontrol positif, yaitu tabung yang berisi Streptococcus mutans setara dengan standar kekeruhan McFarland 1. Tabung 11 diberi label K(-) yang merupakan kontrol negatif, yaitu tabung berisi ekstrak daun pacar air dengan konsentrasi $100 \%$. Tabung 1 diisi sebanyak $4 \mathrm{ml}$ konsentrasi $100 \%$ ekstrak daun pacar air. Tabung 2-9 diisi dengan $2 \mathrm{ml}$ media cair BHI. Kemudian ambil 2 ml larutan dari tabung 1, dimasukkan ke dalam tabung 2, dicampur hingga homogen sehingga didapatkan konsentrasi $50 \%$. Hal yang sama dilakukan hingga tabung 9 hingga didapatkan semua konsentrasi ekstrak.

Pada pengujian menggunakan turbid-

metri, setelah media tabung perlakuan diinkubasi selama 1×24 jam, semua tabung tersebut dilihat kekeruhannya secara visual. Bila kekeruhan masing-masing tabung masih setara atau lebih keruh dari tabung $\mathrm{K}(+)$ yang berisi suspensi bakteri Streptococcus mutans sesuai standar kekeruhan McFarland 1 berarti bakteri masih dapat bertumbuh, tetapi ketika larutan dalam tabung terlihat mulai lebih jernih daripada tabung $K(+)$ berarti pertumbuhan bakteri mulai terhambat yang menunjukkan KHM.

Pengukuran menggunakan spektrofotometer sesudah media tabung perlakuan diinkubasi selama 1x24 jam, semua tabung perlakuan diukur lagi nilai absorbannya dengan spektrofotometer sebagai nilai absorban akhir. Jika nilai absorban akhir (sesudah inkubasi) masing-masing tabung lebih besar dari nilai absorban awal (sebelum inkubasi), maka disimpulkan bahwa masih terjadi pertumbuhan bakteri, namun jika tidak terdapat perubahan nilai absorban antara nilai absorban akhir dengan absorban awal, atau nilai absorban akhir lebih kecil dari nilai absorban awal, maka disimpulkan bahwa pertumbuhan bakteri dihambat. KHM ditentukan dengan konsentrasi ekstrak terkecil pada tabung perlakuan yang sudah mulai menghambat pertumbuhan bakteri.

\section{HASIL PENELITIAN}

Melalui penelitian yang dilakukan di Laboratorium Farmasi Fakultas MIPA Universitas Sam Ratulangi didapatkan data tentang kadar hambat minimum ekstrak daun pacar air terhadap Streptococcus mutans, yang dilihat menggunakan metode turbidimetri dan Spektrofotometer UV-Vis.

Tabel 1 menunjukan bahwa pengujian menggunakan metode turbidimetri dengan tiga kali perlakuan. Pada perlakuan pertama, kedua dan ketiga menunjukkan konsentrasi hambat minimum (KHM) terlihat pada konsentrasi 6,25\%.

Tabel 2 menunjukkan bahwa pada konsentrasi 3,125\% telah terjadi penurunan nilai absorbansi, kemudian pada konsentrasi $1,56 \%$ terjadi kenaikan nilai absorbansi hingga konsentrasi paling akhir $0,39 \%$. Pada konsentrasi $3,125 \%$ terjadi penurunan dan diikuti konsentrasi $6,25 \%$ $100 \%$ terus terjadi penurunan, sehingga konsentrasi $3,125 \%$ ditetapkan sebagai kadar hambat minimum ekstrak daun pacar air terhadap pertumbuhan Streptococcus mutans. 
Tabel 1. Hasil pengujian menggunakan metode turbidimetri dari ekstrak daun pacar air terhadap pertumbuhan Streptococcus mutans.

\begin{tabular}{ccccc}
\hline \multirow{2}{*}{$\begin{array}{c}\text { Nomor } \\
\text { tabung }\end{array}$} & $\begin{array}{c}\text { Konsentrasi ekstrak } \\
\text { daun Pacar Air }\end{array}$ & $\begin{array}{c}\text { Perlakuan } \\
\text { Pertama }\end{array}$ & $\begin{array}{c}\text { Perlakuan } \\
\text { Kedua }\end{array}$ & $\begin{array}{c}\text { Perlakuan } \\
\text { Ketiga }\end{array}$ \\
\hline 1 & $100 \%$ & - & - & - \\
2 & $50 \% \%$ & - & - & - \\
3 & $25 \%$ & - & - & - \\
4 & $12,5 \%$ & - & - & - \\
$\mathbf{5}$ & $\mathbf{6 , 2 5 \%}$ & + & + & + \\
6 & $3,125 \%$ & + & + & + \\
7 & $1,56 \%$ & + & + & + \\
8 & $0,78 \%$ & + & + & + \\
9 & $0,39 \%$ & + & + & - \\
10 & $\mathrm{~K}(+)$ & - & - & + \\
11 & $\mathrm{~K}(-)$ & + & + & + \\
\hline
\end{tabular}

Keterangan: Tanda "+" menunjukkan larutan di dalam tabung terlihat keruh yang berarti bahwa bakteri Streptococcus mutans masih dapat bertumbuh; sedangkan tanda "“" menunjukkan larutan di dalam tabung terlihat jernih yang berarti bahwa pertumbuhan bakteri Streptococcus mutans terhambat.

Tabel 2. Hasil pengujian menggunakan spetrofotometer UV-Vis ekstrak daun pacar air terhadap pertumbuhan Streptococcous mutans.

\begin{tabular}{|c|c|c|c|c|c|c|c|c|c|}
\hline \multirow{4}{*}{$\begin{array}{c}\text { Konsentrasi ekstrak } \\
\text { Daun Pacar Air }\end{array}$} & \multicolumn{8}{|c|}{ Hasil } & \multirow[t]{4}{*}{ Ket } \\
\hline & \multicolumn{2}{|c|}{ Perlakuan I } & \multicolumn{2}{|c|}{ Perlakuan II } & \multicolumn{2}{|c|}{ Perlakuan III } & \multicolumn{2}{|c|}{ Rata-Rata } & \\
\hline & Sebelum & Sesudah & Sebelum & Sesudah & Sebelum & Sesudah & Sebelum & Sesudah & \\
\hline & Inkubasi & Inkubasi & Inkubasi & Inkubasi & Inkubasi & Inkubasi & Inkubasi & Inkubasi & \\
\hline $100 \%$ & 3,637 & 2,038 & 3,974 & 3,745 & 3,925 & 4,000 & 3,845 & 3,261 & Turun \\
\hline $50 \%$ & 3,868 & 3,769 & 4,000 & 3,769 & 3,868 & 3,838 & 3,902 & 3,750 & Turun \\
\hline $25 \%$ & 3,674 & 3,835 & 3,799 & 3,538 & 3,841 & 3,763 & 3,771 & 3,712 & Turun \\
\hline $12,5 \%$ & 3,594 & 3,566 & 3,594 & 3,383 & 3,931 & 3,841 & 3,706 & 3,663 & Turun \\
\hline $6,25 \%$ & 3,744 & 3,636 & 3,008 & 3,098 & 3,654 & 3,523 & 3,468 & 3,419 & Turun \\
\hline $3,125 \%$ & 3,424 & 3,468 & 4,000 & 3,857 & 4,000 & 3,857 & 3,808 & 3,727 & Turun \\
\hline $1,56 \%$ & 3,664 & 3,852 & 3,718 & 3,473 & 3,135 & 3,530 & 3,505 & 3,618 & Naik \\
\hline $0,78 \%$ & 3,583 & 3,614 & 3,499 & 3,871 & 3,871 & 3,614 & 3,651 & 3,699 & Naik \\
\hline $0,39 \%$ & 2,877 & 3,749 & 3,622 & 4,000 & 3,005 & 4,000 & 3,168 & 3,916 & Naik \\
\hline $\mathrm{K}(+)$ & 1,099 & 1,017 & 0,440 & 0,682 & 0,310 & 0,595 & 0,616 & 0,764 & Naik \\
\hline K (-) & 1,969 & 1,827 & 1,336 & 1,205 & 1,969 & 1,290 & 1,758 & 1,440 & Turun \\
\hline
\end{tabular}

Keterangan: "Naik" menunjukkan nilai absorbansi setelah inkubasi > nilai absorbansi sebelum inkubasi, yang berarti bahwa terdapat pertumbuhan bakteri; sedangkan "Tetap" atau "Turun" menunjukkan nilai absorbansi setelah inkubasi $\leq$ nilai absorbansi sebelum inkubasi, yang berarti bahwa pertumbuhan bakteri terhambat.

\section{BAHASAN}

Pada penelitian ini dilakukan uji KHM ekstrak daun pacar air terhadap pertumbuhan Streptococcus mutans, dengan menggunakan metode serial dilusi perbandingan $1: 2(\mathrm{w} / \mathrm{v})$ yaitu $100 \%, 50 \%$, $25 \%, \quad 12,5 \%, 6,25 \%, 3,125 \%, 1,56 \%$, $0,78 \%$, dan $0,39 \%$. Terdapat dua cara pengujian: 1) Uji turbidimetri, yaitu melihat nilai kekeruhan secara visual dan 2) pengukuran nilai absorbansi menggunakan spektrofotometer UV-Vis. Perlakuan dilakukan setelah diinkubasi selama 24 jam.

Uji turbidimetri dengan penglihatan secara kasat mata pada 3 kali perlakuan, didapatkan konsentrasi 6,25\% merupakan KHM ekstrak daun pacar air terhadap pertumbuhan Streptococcus mutans. Dengan metode pengujian secara visual (turbidimetri) sudah bisa ditentukan KHM namun metode ini memiliki kelemahan yaitu mata manusia pada saat melakukan pengamatan kekeruhan tidak bisa membedakan antara sel bakteri yang hidup dengan sel bakteri yang mati dan larutan bisa mencapai warna yang pekat sehingga hasil pengamatan kurang akurat. Oleh karena itu perlu dilakukan pengujian lebih lanjut dengan cara mengukur nilai absorbansi menggunakan spektrofotometer UV-Vis agar lebih akurat. ${ }^{6,7}$ 
Pengukuran menggunakan spektrofotometer UV-Vis dilakukan sebelum dan sesudah inkubasi 24 jam yang dilihat melalui selisih hasil pengukuran nilai absorbansi sebelum dan sesudah inkubasi. Jika nilai absorbansi sebelum diinkubasi lebih tinggi dibandingkan nilai absorbansi sesudah diinkubasi maka pertumbuhan bakteri tehambat. Sebaliknya jika nilai absorbansi sesudah inkubasi lebih tinggi dibandingkan sebelum diinkubasi maka masih terjadi pertumbuhan bakteri. ${ }^{8}$ Inkubasi dilakukan dengan tujuan untuk mendapatkan sebuah biakan yang murni tanpa adanya mikroba lain yang tidak diinginkan ikut tumbuh. ${ }^{9}$

Pada konsentrasi 3,125\% terjadi penurunan nilai absorban dan pada konsentrasi berikutnya juga terjadi penurunan, maka dapat disimpulkan bahwa konsentrasi 3,125\% merupakan KHM ekstrak daun pacar air terhadap partumbuhan bakteri Streptococcus mutans.

Melalui hasil penelitian terdapat perbedaan KHM ekstrak daun pacar air terhadap pertumbuhan Streptococcus mutans yang dianalisis menggunakan metode turbidimetri dan spektrofotometer UV-Vis. Hal ini dapat disebabkan karena adanya perbedaan prinsip kerja dari masing-masing metode. Pada metode turbidimetri peneliti hanya melihat hasil secara visual, dengan melihat kekeruhannya, jadi dapat dikatakan hasilnya cenderung bersifat subjektif., ${ }^{7,8}$ Metode spektrofotometer UV-Vis juga masih memiliki kekurangan dalam selektivitas untuk membedakan sampel dengan partikel-partikel lain atau kontaminan yang menyerap cahaya dalam panjang gelombang yang sama. Kelebihan metode spektrofotometer UV-Vis yaitu hasil yang didapatkan bersifat kuantitatif sehingga dapat dikatakan hasilnya lebih akurat. ${ }^{10,11}$

Kromatografi Cair Kinerja Tinggi (KCKT) atau High Pressure Liquid Chromatography (HPLC) merupakan salah satu metode kimia dan fisikokimia. KCKT termasuk metode analisis terbaru yaitu suatu teknik kromatografi dengan fasa gerak cairan dan fasa diam cairan atau padat. Metode ini mempunyai banyak kelebihan jika dibandingkan dengan metode lainnya. ${ }^{12}$ Penelitian yang dilakukan oleh Joshi et al. ${ }^{13}$ tahun 2010 di India membandingkan metode spektrofotometri dengan metode HPLC dan menyimpulkan bahwa metode HPLC memiliki hasil yang lebih baik dari pada metode spektrofotometri dari segi keakuratan, ketelitian, dan sensitivitas dalam membaca nilai absorbansi.

Uji KHM ekstrak daun Pacar Air terhadap pertumbuhan Streptococcus mutans belum pernah dilakukan sebelumnya. Pada penelitian ini, konsentrasi hambat minimum (KHM) ekstrak daun Pacar Air (Impatiens balsamina linn) terhadap pertumbuhan Streptococcus mutans yaitu konsentrasi $3,125 \%$ yang diperoleh melalui hasil pengukuran dengan spektrofotometer UV-Vis.

\section{SIMPULAN}

Konsentrasi hambat minimum ekstrak daun Pacar Air (Impatiens balsamina Linn) terhadap bakteri Streptococcus mutans terdapat pada konsentrasi 3,125\%.

\section{SARAN}

Disarankan untuk penelitian lanjutan mengenai uji konsentrasi hambat minimum (KHM) ekstrak daun Pacar Air (Impatiens balsamina L.) terhadap pertumbuhan Streptococcus mutans dengan menggunakan metode High-Performance Liquid Chromatography (HPLC) untuk memperoleh hasil yang lebih akurat. Dapat dilakukan penelitian lebih lanjut mengenai nilai konsentrasi bunuh minimum (KBM) ekstrak daun Pacar Air terhadap pertumbuhan Streptococcus mutans.

Diperlukan penelitian lanjutan tentang toksisitas senyawa aktif dari ekstrak daun Pacar Air untuk keamanan penggunaan bagi manusia.

\section{DAFTAR PUSTAKA}

1. Badan Penelitian dan Pengembangan Kesehatan. Riset Kesehatan Dasar Riskesdas 2013. Jakarta: Kementerian Kesehatan RI, 2013; p. 147-54. 
2. Kidd EAM. Joyston S. Dasar-dasar Karies Penyakit dan Penanggulangannya. Jakarta: EGC; p.1-2.

3. Zain NBM. Differential expression of gene of streptococcus mutans in response to treat with piper betle aqueous extract a research framework. IPCBEE. 2011;5:467.

4. Niu C, Gilbert ES. Colorimetric method for identifying plant essential oil components that affect biofilm formation and structure. Appl Environ Microbiol. 2004;70(12): 6951-6.

5. Harmita, Radji M. Buku Ajar Analisis Hayati (3rd ed). Jakarta: EGC; p. 4.

6. Michel C, Blanc G. Minimum inhibitory concentration methodology in aquaculture: the temperature. Aquaculture. 2001;196:311-8.

7. Septian K. Uji Konsentrasi Hambat Minimum (KHM) ekstrak spons laut Callyspongia sp. terhadap pertumbuhan Staphylococcus aureus. Dentire. 2016;5(1): 510.

8. Sitompul R. Uji Konsentrasi Hambat Minimum (KHM) ekstrak daun Gedi (Abelmoschus manihot L. Medik) terhadap pertumbuhan Staphylococcus aureus. Dentire. 2016;5(1):21-7.

9. Harti SA. Mikrobiologi Kesehatan (1st ed). Yogyakarta: Penerbit Andi, 2015; p. 124-6.

10. Watson DG. Pharmaceutical Analysis (2nd ed). London: Elsevier, 2005; p. 88.

11. Cioabla AE, editor. Spectrophotometry. Principle and Applications.Workshop in the frame of the project: sustainable development of a research center in Banat region and Danube flow area through scientific research and environmental simulation tools to asses and evaluate potential threats. Zrenjanin, Republic of Serbia: Envirobanat, 2013; p. 1.

12. Putra EDL. Kromatografi cair kinerja tinggi dalam bidang farmasi. Medan; Universitas Sumatera Utara; 2004; p. 12.

13. Joshi HR, Patel AH, Captain AD. Spectrophotometric and ReversedPhase High-Performance Liquid Chromatographic method for determination of doxophylline in pharmaceutical formulations. J Young Pharm. 2010;2(3):289-96. 